\title{
MAKNA KONTEKSTUAL DALAM LAGU LUKAH GILO PADA MASYARAKAT KABUPATEN TEBO PROVINSI JAMBI (STRUKTURAL HERMENEUTIK)
}

\author{
Septi Rahmawati ${ }^{1}$, Ade Rahima ${ }^{2}$ \\ Program Studi Pendidikan Bahasa dan Sastra Indonesia, \\ Fakultas Keguruan dan Ilmu Pendidikan, Universitas Batanghari, \\ Jambi \\ Rahmawatisepti22@gmail.com \\ ade.rahima@unbari.ac.id
}

\begin{abstract}
This research is aimed at describing contextual meaning in the song lukah gilo of Tebo Regency society Jambi city. This research is qualitative descriptive. The data is the lyric of lukah gilo song of Tebo regency society Jambi city (Hermeneutics structural). Meanwhile the technique of collecting data is observation, interview, and recording. The result of this research shows the description of how contextual meaning in the song lukah gilo of Tebo regency society Jambi city (hermeneutics structural), they are: (1) Contextual meaning on the song lyric of lukah gilo related with lexical meaning, (2) Contextual meaning which is related with situational context (place and time), (3) Contextual meaning which is related with belief, (4) Contextual meaning which is related with animism, (5) Contextual meaning which is related with faith. The contextual meaning in the song lukah gilo consists of 72 lines and dan 11 verses.
\end{abstract}

Keywords: Contextual Meaning, Lukah Gilo

\footnotetext{
${ }^{1}$ Mahasiswa Program Studi Pendidikan Bahasa dan Sastra Indonesia, Fakultas Keguruan dan Ilmu Pendidikan, Universitas Batanghari, Jambi

${ }^{2}$ Dosen Program Studi Pendidikan Bahasa dan Sastra Indonesia, Fakultas Keguruan dan Ilmu Pendidikan, Universitas Batanghari, Jambi
}

Makna Kontekstual dalam Lagu Lukah Gilo pada Masyarakat Kabupaten Tebo Provinsi Jambi (Struktural Hermeneutik) 


\section{PENDAHULUAN}

Proses komunikasi dapat dilakukan melalui bahasa. "Bahasa adalah sebuah sistem lambang yang menghubungkan dunia makna dan dunia bunyi serta terkait erat dengan dunia pragmatik (Chaer, 2015: 15)". Konsep tersebut menjelaskan bahwa bahasa mempunyai lambang bunyi yang mengandung makna yang berfungsi seagai alat komunikasi antarpembicara dan pendengarnya. Oleh karena itu, tanpa bahasa, komunikasi tidak dapat dilakukan dengan baik dan interaksi sosial pun tidak pernah terjadi. Fungsi bahasa yang paling mendasar ialah sebagai alat komunikasi (Rofii dan Hasibuan, 2019). Komunikasi tujuan untuk menyampaikan informasi baik dilakukan melalui lisan maupun tulisan. Komunikasi secara tulisan pada zaman modern seperti saat ini sangat mudah dilakukan. Tanpa bahasa, seseorang tidak mampu mengekspresikan dan menyampaikan suatu pesan kepada orang lain. Hal inilah yang melatarbelakangi peneliti mengambil objek bahasa karena pentingnya fungsi bahasa sebagai sarana dalam bersastra salah satunya jenisnya, yaitu sastra lisan. Salah satu jenis sastra lisan yang masih bertahan adalah lagu daerah.

Penelitian tentang kajian sastra lisan masyarakat Melayu Jambi sudah banyak dilakulakan. Namun kajian tentang makna sastra lisan dengan pendekatan struktural hermeneutik masih jarang. Ada 2 penelitian yang relevan dengan penelitian ini yang juga peneliti lakukan antara lain: 1) Interpretasi Makna Simbolik Ungkapan Tradisional Seloko Hukum Adat Melayu Jambi. Penelitian ini dilakukan pada tahun 2014 dan 2) Nilai-nilai Religius Seloko Adat pada Masyarakat Melayu Jambi (Telaah Struktural Hermeuitik). Penelitian ini dilakukan pada tahun 2017.
Dalam penelitian ini, digunakan lagu daerah sebagai salah satu bentuk sastra lisan dari Kabupaten Tebo, Provinsi Jambi yaitu Lukah Gilo. Hal ini dimaksudkan untuk mengembangkan sastra lisan lagu daerah tersebut agar tidak dilisankan saja tetapi juga dikembangkan menjadi tari-tarian yang diiringi musik. Begitupun musik tradisional saat ini sudah mengikuti zaman menjadi musik modern. Selain itu, Lukah Gilo ini salah satu kesenian yang dapat dipertunjukkan untuk mampu menyatukan berbagai kalangan masyarakat dari berbagai latar belakang usia, suku, agama dan jenis kelamin melalui lirik yang terkandung dalam lagu daerah Lukah Gilo.

Lagu daerah Lukah Gilo memiliki keunikan bahasa tersendiri. Bahasa dan dialek yang digunakan terkadang sulit untuk dipahami maksud dan tujuannya karena isi dari lirik lagu daerah susah untuk dipahami tidak semua orang bisa memahami isi dari lirik lagu daerah tersebut. Lirik lagu memiliki bentuk pesan berupa kalimat yang dapat digunakan untuk menggambarkan keadaan tertentu kepada pendengar sehingga menciptakan makna yang beragam. Oleh karena itu, lirik lagu daerah memiliki makna pada kata-kata yang tidak semua orang mengerti maksud dari lagu daerah khususnya lagu Lukah Gilo yang berkaitan dengan kejelasan makna pada lirik lagu.

Berdasarkan hasil wawancara dengan salah satu staf Dinas Pendidikan Kebudayaan dan Pariwisata Provinsi Jambi, Eri Argawan (09/11/2018) diketahui bahwa "Lagu daerah adalah warisan budaya tidak benda yang dilindungi oleh negara". Lagu daerah dari Kabupaten Tebo dinyanyikan oleh masyarakat sesuai dengan bahasa seharihari sebagai penyemangat saat selesai beraktivitas yang dinyanyikan bersama- 
sama. Lagu daerah di setiap daerah memiliki ciri khas yang menarik perhatian oleh khalayak dan menjadi kebanggan masyarakatnya tersendiri. Lagu daerah pada saat ini sudah mulai jarang dinyanyikan karena kebudayaan luar masuk ke Indonesia dan bahasa lagu daerah yang susah untuk dipahami sehingga lagu daerah hanya diminati oleh orangtua saja.

Lagu daerah yang susah untuk dipahami sehingga lagu daerah hanya diminati oleh orang- orang tua. Pada hal lagu ini merupakan salah satu bentuk kearifan lokal yang harus dikembangkan oleh masyarakat sebagai salah satu kesenian warisan leluhur. Menurut Dora (2018: 3) "Kearifan lokal adalah kepribadian, identitas kultural masyarakat yang berupa nilai, norma, etika, kepercayaan, adat istiadat dan aturan khusus yang telah teruji kemampuannya sehingga dapat terus menerus". Kearifan lokal inilah yang harus dikembangkan khususnya untuk lagu daerah Kabupaten Tebo agar bisa dinikmati dari generasi ke generasi ke depannya.

Penelitian mengenai lagu daerah khususnya lagu daerah Kabupaten Tebo, Provinsi Jambi untuk mendokumentasikan sehingga masyarakat Tebo mengetahui akan budaya tradisional warisan leluhur dan diharakan bisa dibaca oleh masyarakat luas khususnya untuk masyarakat kabupaten Tebo dan menumbuhkan kesadaran untuk mencintai budaya lokal. Selain itu, penelitian ini juga memperkenalkan makna lagu daerah dari Kabupaten Tebo ke masyarakat luas dan bisa dimengerti makna lagu Lukah Gilo oleh orang banyak khususnya masyarakat Kabupaten Tebo. Makna kontekstual dipilih sebagai sesuatu hal yang menarik karena lirik lagu Lukah Gilo mengandung makna leksikal dan tekstual yang dapat dilihat dalam kamus kosakata juga makna kontekstual yang sulit dipahami oleh pembaca. contohnya:

"Yasi-yasi sifat sia lukah Lah galenggang tumbohlah direnah Capocapo tumbolah dibukit Ilie lukah mudik lukah"

Maka dari itu makna kontekstual memerlukan pemahaman yang mendalam. Menurut Suwandi (2011: 84) "Makna kontekstual adalah makna yang muncul sebagai akibat hubungan antara ujaran dan situasi pada waktu ujaran dipakai". Maka konteks dapat pula berkenaan dengan situasi yakni tempat, waktu dan lingkungan penggunaan bahasa itu.

Berdasarkan uraian di atas dapat disimpulkan bahwa empat alasan dipilihnya judul Makna Kontesktual dalam Lagu Lukah Gilo pada Masyarakat Kabupaten Tebo, Provinsi Jambi yang mencakup hal-hal berikut.

1. Pentingnya penelitian fungsi bahasa sebagai sarana dalam bersastra salah satunya sastra lisan karena sastra lisan mulai tergerus globalisasi.

2. Pentingnya mengembangkan sastra lisan berupa lagu daerah dari Kabupaten Tebo karena lagu daerah saat ini sudah jarang diperdengarkan akibat budaya luar masuk ke Indonesia.

3. Pentingnya lirik lagu yang menggambarkan tradisi masyarakat Kabupaten Tebo sebagai penyemangat saat selesai berakitivitas yang dinyanyikan bersama-sama.

4. Pentingnya memahami makna kontekstual dalam lirik lagu untuk dapat dipublikasikan ke pembaca dan semua orang bisa memahami isi dari lirik lagu khususnya lagu Lukah Gilo.

Fokus merupakan pusat perhatian penelitian yang dijadikan titik tolak masalah. Adapun yang menjadi fokus penelitian ini terkait dengan makna kontekstual pada lagu Lukah Gilo di 
masyarakat Kabupaten Tebo Provinsi Jambi.

Berdasarkan fokus penelitian di atas dapat dikemukakan pertanyaan penelitian. Ada pun irumuskan pertanyaan penelitian yaitu Bagaimanakah makna kontekstual yang terdapat lagu Lukah Gilo pada masyarakat Kabupaten Tebo Provinsi Jambi?

Tujuan penelitian merupakan sasaran yang ingin dicapai dalam penelitian ini sesuai dengan permasalahan yang telah dirumuskan. Berdasarkan fokus penelitian dan pertanyaan penelitian yang telah diuraikan, maka tujuan dari penelitian ini adalah mendeskripsikan makna kontekstual lagu Lukah Gilo pada masyarakat Kabupaten Tebo Provinsi Jambi.

\section{Kajian Teoretis}

Makna leksikal sering disebut makna yang sesuai dengan kamus. Lexical meaning is the meaning of the word attached to a lexicon (Rofii, 2017). Chaer (2002: 60) mengatakan "Makna leksikal adalah makna yang sesuai dengan referennya, makna yang sesuai dengan hasil observasi alat indera atau makna yang sungguh-sungguh nyata dalam kehidupan kita". Seperti halnya fonem di dalam fonologi, morfem di dalam morfologi, leksem juga bersifat abstrak. Leksem menjadi dasar pembentukan suatu kata dan makna dapat diidentifikasikan tanpa menggabungkan unsur satu dengan unsur yang lain.

Makna gramatikal adalah makna yang muncul sebagai akibat berfungsinya leksem di dalam kalimat. Menurut Kridalaksana (dalam Suwandi, 2011: 81) "Makna gramatikal menunjuk pada hubungan antara unsur-unsur bahasa dalam satuan-satuan yang lebih besar, misalnya hubungan antara kata dengan kata lain dalam frasa atau klausa”. Makna gramatikal merupakan makna yang muncul sebagai hasil proses gramatikal untuk itulah kemampuan aspek gramatika sangat menentukan keberhasilan komunikasi.

Makna teks ialah suatu usaha dalam memahami makna dari teks. Menurut Anshari (2009: 192) "Makna teks adalah bentuk simbolik dan konseptual yang bertujuan tidak sekedar mengetahui dan mengenali struktur bentuk dan bahasa, tetapi justru lebih penting adalah makna yang tersirat dan tersurat". Makna dari sebuah teks untuk memahami struktur tekstual agar bisa membimbing pembaca ke arah suatu makna tertentu. Menurut Hirsch (dalam Ellen, 2004: 2) "Makna teks adalah suatu artian yang di dalamnya tidak bisa mengevaluasi sebuah teks maupun menetapkan apa maksudnya sebelum memahami betul apa yang dimaksud". Makna tergantung pada kata-kata lain yang membentuk kalimat.

Dalam pertuturan sehari-hari kita jarang sekali menggunakan kata-kata dalam makna leksikal maupun gramatikal kita lebih banyak menggunakan kata-kata dalam makna kontekstual karena sering dikatakan sebuah kata baru jelas maknanya setelah kata itu berada di dalam konteksnya. Konteks bisa berupa konteks linguistik, konteks situasi (tempat dan waktu), konteks bidang kegiatan atau keilmuan, bidang sosial dan budaya, atau konteks lainnya (Chaer, 2007: 119).

Bidang kebudayaan ialah suatu bidang tentang budaya atau kebiasaan dalam masyarakat yang tinggal di daerah tertentu. Sarinah (2016: 11) mengemukakan "Budaya adalah suatu cara hidup yang berkembang dan dimiliki bersama oleh sebuah kelompok orang dan diwariskan dari generasi ke generasi”. Bidang kebudayaan yang 
memiliki keseluruhan yang kompleks yang di dalamnya terkandung pengetahuan, kepercayaan, adat istiadat dan kemampuan-kemampuan lain yang didapat seseorang sebagai anggota masyarakat.

Animisme ialah kepercayaan terhadap roh-roh halus yang memiliki kekuatan ghaib. Tylor (dalam Sutardi, 2007: 25) mengungkapkan "Animisme adalah kepercayaan manusia yang memiliki hubungan antara manusia dan roh halus ini dilakukan dengan tata cara keagaman, seperti: pemberian sesajen, pembacaan mantra dan doa-doa, membakar kemenyan, melakukan tarian, nyanyian suci dan sebagainya". Roh-roh halus ada di mana-mana bahkan dapat memasuki tubuh manusia yang lemah sehingga manusia menghormati dan meminta perlindungan dari roh-roh tersebut.

Asal mula timbulnya religi ialah tumbuhnya kesadaran pada diri manusia tentang adanya jiwa dan roh. Menurut Koentjaraningrat (dalam Sutardi, 2007: 24) "Bidang keyakinan dalam religi manusia berwujud nilai-nilai tentang keyakinan dan konsep manusia akan sifat-sifat tuhan, alam gaib, kejadiankejadian alam, kekuatan sakti serta makhluk halus( gaib)". Keyakinan ialah suatu sikap yang ditunjukkan oleh manusia yang tidak selalu benar.

Struktural ialah struktur atau susunan yang memiliki makna. Bertens (dalam Rahima, 2017: 254) mejelaskan bahwa "Struktural mengembangkan gagasan bahwa sebuah teks sastra adalah sebuah struktur dimana semua elemen atau unsurnya saling terikat dan saling mempengaruhi”. Setiap satu kesatuan yang utuh terdiri dari unsur-unsur yang saling terkait dan membangun kesatuan yang lengkap. Pemaknaan harus dihubungkan antar unsur secara keseluruhan.
Hermeneutik berasal dari kata hermeneuein, dan kata benda hermenia yang berarti penafsiran atau interpretasi. Menurut Ricoeur (dalam Saidi, 2008: 377) "Hermeneutik adalah menafsirkan makna dan pesan seobjektif mungkin sesuai diinginkan teks". Menurut Rahima (2016:Objektivitas dapat dicapai atau subjektivitas dapat menggunakan gambar yang berupa pramida terbalik sebagi berikut:

\section{Gambar 1:}

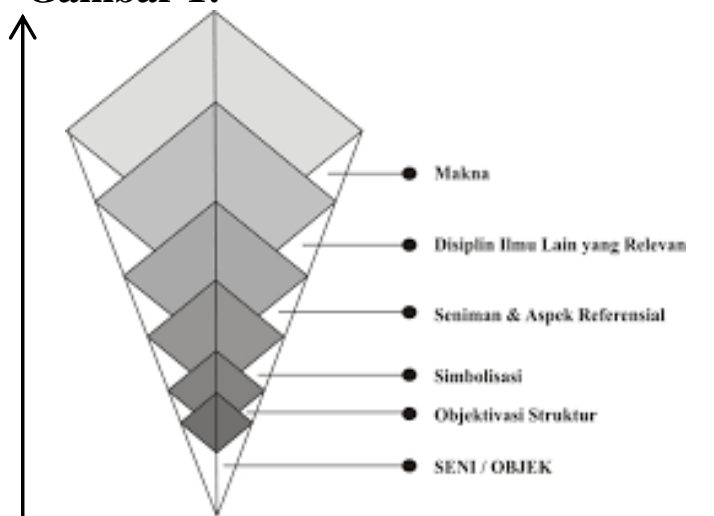

1. Mula-mula teks (seni) ditempatkan sebagai objek yang diteliti sekaligus sebagai subjek atau pusat yang otonom.

2. Karya seni sebagai fakta ontologi dipahami dengan cara mengobjektivitasi strukturnya. Disini analisis struktural menempati posisi penting.

3. Pemahaman semakin meluas ketika masuk pada lapis simbolisasi. Hal ini terjadi sebab disisni tafsir telah melampaui batas struktur.

4. Kode-kode simbolik yang dipancarkan teks dan dikaitkan dengan berbagai persoalan diluar dirinya menuntut disiplin ilmu lain untuk melengkapi tafsir.

Akhirnya, ujung dari proses itu adalah ditemukannya makna atau pesan. Dari skema tampak bahwa makna dan pesan dalam tafsir hermeneutik berada pada wilayah yang paling luas dan paling berjauhan dengan teks (karya seni sebagai fakta ontologisnya), tetapi tetap 
berada di dalam horizon yang dipancarkan teks.

Berdasarkan hasil wawancara peneliti dan informan Bapak Pajri (11/03/2019), Lukah gilo ialah suatu permainan yang mengandung unsur mistis berbentuk boneka diiringi nyanyian dan alat musik yang berasal dari Desa Semabu, Kabupaten Tebo, Provinsi Jambi yang telah dimainkan dari generasi ke generasi. Lukah gilo biasa dimainkan oleh masyarakat setempat saat sesudah panen padi, upacara pernikahan yang dipimpin oleh orang yang memahami tentang lukah gilo (dukun) dan 2 orang pemegang boneka. Dalam melakukan kegiatan ini memiliki 3 tahapan, yaitu: tahap persiapan, tahap pelaksanaan dan tahap akhir.

\section{METODE PENELITIAN}

Jenis penelitian merupakan cara kerja suatu penelitian dalam memahami objek yang akan dilaksanakan (Gunawan, Rahima, dan Supriyati, 2017:1).

Jenis penelitian yang peneliti gunakan dalam penelitian makna kontekstual lagu Lukah Gilo pada Masyarakat Kabupaten Tebo Provinsi Jambi menggunakan pendekatan kualitataif. Sugiyono (2016: 2) menyatakan bahwa "Metode penelitian pada dasarnya merupakan cara ilmiah untuk mendapatkan data dengan tujuan kegunaan tertentu". Dalam penelitian ini digunakan metode penelitian bahasa yang bertujuan mengumpulkan data.

Dalam penelitian deskriptif dikumpulkan data berupa kata-kata atau gambaran bukan angka-angka. Moleong (dalam Muhammad, 2011: 30) mengungkapkan "Metodologi kualitatif sebagai prosedur penelitian yang menghasilkan data deskriptif berupa katakata tertulis atau lisan dari orang-orang dan perilaku yang diamati". Penelitian kualitatif yang bersifat deskriptif ialah berbentuk data dari sebuah fenomena atau gejala-gejala tidak berupa angkaangka. Metode deskriptif kualitatif suatu proses permasalahan yang mendeskripkan atau menggambarkan penelitian berdasarkan fakta-fakta yang ada.

Data merupakan hal yang penting dalam penelitian karena data merupakan hal utama dalam penelitian. Penelitian ini menggunakan dua jenis data, yaitu: data primer yang diperoleh langsung dari sumber asli. Menurut Sugiyono (2016: 222) "Data primer adalah data yang langsung memberikan data kepada pengumpul data". Jadi, data primer ini berupa catatan hasil observasi dan wawancara yang peneliti lakukan. Selain itu, data primer dalam penelitian ini mengenai lagu Lukah Gilo pada Masyarakat Kabupaten Tebo, Provinsi Jambi.

Data sekunder ialah data yang diperoleh tidak langsung dari sumber data atau melalui media. Menurut Sugiyono (2016: 222) "Data sekunder merupakan sumber yang tidak langsung memberikan data kepada pengumpul data, misalnya lewat orang lain atau lewat dokumen". Dalam penelitian ini peneliti mendapatkan data sekunder bisa melalui masyarakat yang menjadi informan peneliti yang dianggap memahami lagu Lukah Gilo sebagai data pelengkap.

Sumber data berasal dari informan yang memahami lagu Lukah Gilo. Dalam penelitian ini peneliti mengambil sumber data yang akurat dari informan yang dapat dipercaya dan dianggap dapat mewakili masyarakat Desa Semabu, Kabupaten Tebo.

Teknik pengumpulan data dapat digunakan oleh peneliti dalam mengumpulkan data untuk penelitian. Pengumpulan data yang digunakan dalam penelitian makna kontekstual dalam teks lagu Lukah Gilo dari Kabupaten Tebo, 
Provinsi Jambi. Pengumpulan data dalam penelitian ini dilakukan melalui observasi dan wawancara.

Observasi dalam penelitian ini untuk mengumpulkan data yang diinginkan. Menurut Margono (2014: 158) "Observasi diartikan sebagai pengamatan dan pencatatan yang dilakukan terhadap objek ditempat terjadi atau berlangsungnya peristiwa". Oleh karena itu, peneliti melakukan observasi bertujuan untuk melakukan pengamatan secara langsung tentang isi dari lagu Lukah Gilo dari Kabupaten Tebo Provinsi Jambi. Berdasarkan observasi peneliti mencari informasi tentang informan yang memahami lagu Lukah Gilo.

Wawancara ini untuk mendapatkan informasi dari narasumber. Menurut Muhammad (2011: 195) "Wawancara adalah pengumpulan data untuk melakukan percakapan dengan para informan". Komunikasi berlangsung dalam bentuk tanya-jawab untuk mendapatkan suatu data yang diteliti. Dalam penelitian ini peneliti melakukan teknik wawancara untuk mendapatkan pemahaman tentang makna lagu termasuk pemahaman setiap lirik atau bait yang terdapat lagu Lukah Gilo dari narasumber atau informan.

Sugiyono

(2018:

menyatakan "Wawancara terstruktur digunakan sebagai teknik pengumpulan data, bila peneliti atau pengumpul data mengetahui dengan pasti tentang informasi apa yang diperoleh".

Subjek penelitian ialah orang yang diminta keterangan tentang suatu fakta atau pendapat. Menurut Fitrah dan Luthfiyah (2017: 152) "Subjek penelitian adalah seseorang yang merujuk pada responden atau informan yang hendak dimintai informasi atau digali datanya, sedangkan objek merujuk pada masalah atau tema yang diteliti”. Jadi, subjek penelitian ini merupakan sumber informasi dari informan yang digali datanya untuk mengungkapkan faktafakta di lapangan. Adapun yang menjadi subjek penelitian peneliti ini menetapkan 2 orang yang dianggap memahami tentang isi dari lagu Lukah Gilo sebagai informan. Persyaratan yang dipakai untuk pemilihan sampel menurut Mashun (dalam Muhammad, 2011: 193) dan disesuaikan rekayasa peneliti sebagai berikut.

1. Berjenis kelamin pria atau wanita.

2. Berusia antara 25-65 tahun (tidak pikun).

3. Orangtua, istri atau suami informan lahir dan dibesarkan di desa itu serta jarang atau tidak pernah meninggalkan desanya.

4. Berpendidikan maksimal tamat pendidikan dasar (SD-SMP).

5. Pekerjaannya bertani atau buruh.

6. Memiliki kebanggaan terhadap isoleknya.

7. Sehat jasmani dan rohani.

Menurut Margono (2014: 155) mengungkapkan "Instrumen penelitian adalah alat pengumpulan data yang harus betul-betul dirancang dan dibuat sedemikian rupa sehingga menghasilkan data empiris sebagaimana adanya". Dalam penelitian ini peneliti menggunakan instrumen atau alat sebagai hasil wawancara dapat terekam baik agar peneliti memiliki bukti telah melakukan wawancara bersama informan. Intrumen atau alat-alat yang digunakan sebagai berikut:

1. Alat tulis yang berguna untuk mencatat semua sumber data yang dibutuhkan saat melakukan wawancara ke narasumber.

2. Telepon cerdas (handphone) yang berguna untuk merekam saat peneliti mewawancarai narasumber dan handphone berfungsi mengambil gambar dengan narasumber. 
Teknik analisis data menurut Sugiyono (2016: 244) mengungkapkan "Analisis data adalah proses mencari dan menyusun secara sistematis data yang diperoleh dari hasil wawancara, catatan lapangan dan dokumentasi dengan cara mengorganisasikan data ke dalam kategori, menjabarkan ke dalam unit-unit, melakukan sintesis, menyusun ke dalam pola, memilih mana yang penting dan yang akan dipelajari, membuat kesimpulan sehingga mudah dipahami oleh diri sendiri maupun orang lain".

\section{HASIL DAN PEMBAHASAAN}

Berdasarkan analisis data yang telah peneliti lakukan, maka hasil penelitian mencakup makna kontekstual yang terdapat dalam lagu Lukah Gilo pada masyarakat Kabupeten Tebo, Provinsi Jambi. Makna kontekstual tersebut meliputi 5 aspek, yaitu:

1. makna kontekstual yang terkait dengan makna leksikal,

2. makna kontekstual yang terkait dengan konteks situasi (tempat dan waktu),

3. makna kontekstual yang terkait dengan bidang kebudayaan,

4. makna kontekstual yang terkait dengan bidang animisme, dan

5. makna kontekstual yang terkait dengan bidang keyakinan.

Dalam penelitian ini peneliti menggunakan pendekatan struktural hermeneutik. Data yang dapat diperoleh berdasarkan temuan dari lagu Lukah Gilo yang terdiri dari ada 72 larik dan 11 bait yang akan dijelaskan pada pembahasan.

Berdasarkan hasil yang telah peneliti jelaskan pada bagian di atas maka masing-masing makna kontekstual akan dijelaskan dalam pembahasan berikut. Untuk mendapatkan makna kontekstual melalui struktural hermeneutik dilakukan langkah-langkah yaitu makna leksikal dan makna teks yang memiliki 3 bidang ilmu yaitu bidang kebudayaan, bidang animisme dan bidang keyakinan dengan konteks situasi (tempat dan waktu). Hal ini akan peneliti jelaskan sebagai berikut:

Makna kontekstual yang terkait dengan konteks situasi (tempat dan waktu) pada lagu Lukah Gilo dari Kabupaten Tebo hanya dilaksanakan di pendopo atau rumah, hutan, lapangan dan tidak ada batasan waktu, hal ini akan penulis jabarkan sebagai berikut:

1. Tempat

a. Pendopo dalam kegiatan ini masyarakat Kabupaten Tebo melakukan gotong royang untuk membuat boneka lukah.

b. Hutan atau rimbo dalam pemahaman masyarakat Kabupaten Tebo hutan dipercaya memiliki kekuatan ghaib dan dipercaya sebagai tempat para leluhur mereka terdahulu sehingga tidak sembarangan orang dapat memasuki wilayah tersebut dan saat memasuki hutan tidak boleh berbicara sembarangan.

c. Lapangan dalam pemahaman masyarakat Kabupaten Tebo ialah suatu tempat berkumpul pada acaraacara tertentu, seperti: pentas seni, acara-acara adat dan sebagainya yang membutuhkan tempat yang lebih luas sehingga semua orang bisa menyaksikan acara-acara yang terselenggara. Pada kegiatan permainan lukah gilo biasanya dilakukan dilapangan yang kurang lebih 10 meter

2. Waktu

Dalam pemahan masyarakat Kabupaten Tebo kegiatan permainan lukah gilo tidak ada batasa waktu bisa dilakukan pagi, siang atau malam tergantung situasi dan kondisi tidak ada aturan waktu dalam kegiatan ini.

Makna kontekstual yang terkait dengan bidang budaya lagu lukah gilo ditemukan 4 larik dan 1 bait dari 72 larik 
dan 11 bait. Hal ini akan peneliti jabarkan sebagai berikut:

Yasi-yasi sifat sia lukah:

Dalam kegiatan ini melakukan gotong royong untuk membuat badan boneka yang dibuat langsung oleh masyarakat asli Kabupaten Tebo sebagai suatu kebiasaan dari generasi ke generasi untuk hiburan masyarakat setempat setelah memanen padi atau acara pernikahan. Dalam pembuatan ini pun masyarakat harus memperhatikan caracara pembuatannya, yaitu: lukah atau rekap (sebutan masyarakat Kabupaten Tebo) harus dililitkan terlebih dahulu menggunakan karet berfungsi agar tidak ada angin yang masuk dan sebagai badan boneka, setelah itu lukah dipakaikan sarung sebagai penutup bagian bawah dan bagian atas dikenakan baju bekas, dan terakhir ialah kepala boneka lukah biasanya bagian kepala menggunakan labu manis atau kelapa yang dibuat seperti wajah yang menyeramkan.

Makna kontekstual yang terkait dengan bidang animisme dalam lagu lukah gilo ditemukan 47 larik dan 7 bait dari 72 larik dan 11 bait. Hal ini akan peneliti jabarkan sebagai berikut:

Lah galenggang tumbolah direnah capo-capo tumbohlah dibukit:

Dalam kegiatan ini lukah yang bergoyang-goyang seperti rumput bahwa lukah digerakkan oleh makhluk gaib atau jin yang masuk kedalam badan boneka lukah untuk menari-nari.

\section{Ilie lukah mudik lukah}

Dalam kegiatan ini lukah yang sudah dibacakan mantra akan menghisap atau mengambil energi yang memegang boneka lukah agar lukah bisa bergerak. Pembacaan mantra dilakukan oleh pawang yang memahami.

\section{Main lukah jangan dipermudah}

Dalam kegiatan ini masyarakat setempat percaya bahwa makhluk gaib atau jin yang masuk kedalam lukah untuk bergerak mengikuti alunan musik yang dimainkan pawang. Alat musik yang dimainkan berupa gong atau tetawak ialah sebutan masyarakat Kabupaten Tebo dan gendang.

Tepuk jari sebelah kiri tepuk sampai atas kepalo

Dalam kegiatan ini pawang membakar kemenyan untuk memanggil makluk gaib atau jin agar masuk kedalan badan lukah.

\section{Lenggok kanan lenggok kiri orang nengoklah segalo}

Dalam kegiatan ini jin yang ada dalam lukah masuk ke dalam boneka menari-nari agar semua orang tertarik untuk melihat dan ikut menari.

\section{Hutan tasik hutan tunggal jatuh melayang selero ngenyong}

Pawang yang memanggil makhluk halus atau jin dengan bacaan mantra-mantra oleh pawang untuk masuk kedalam boneka lukah.

\section{Lah babisik jin tunggal utak benak di kepalo ngenyong}

Lukah yang tidak bisa

terkendalikan maka pawang atau yang pemegang lukah memecahkan kepala lukah agar jin bisa keluar. Dalam kegiatan ini makhluk halus atau jin dipulangkan ketempat asalnya.

Makna kontekstual yang terkait dengan bidang keyakinan dalam lagu lukah gilo ditemukan 21 larik dan 3 bait dari 72 larik dan 11 bait. Hal ini akan peneliti jabarkan sebagai berikut:

\section{Cek lukah pandailah menari}

Jin masuk kedalam boneka lukah sehingga lukah bergoyang ke kiri dan ke kanan seperti menari. Dalam pandangan masyarakat Kabupaten Tebo meyakini bahwa kegiatan ini makhluk halus atau gaib masuk ke dalam badan lukah dan menari seperti manusia setelah dibacakan mantra ialah kekuatan makhluk halus atau jin. 


\section{Lah kaduduk tumbuhlah direnah buat budak lanjarlah ketolo}

Dalam pandangan masyarakat Kabupaten Tebo percaya kegiatan ini saat pawang membacakan mantra agar jin yang berada dalam badan boneka bisa keluar dan masyarakat setempat meyakini bahwa makhluk halus atau jin yang berada dalam badan boneka lukah harus dikembalikan keasalnya lagi yaitu ke hutan.

\section{Minta selamat lukahlah dipakai orang nengoklah segalo}

Dalam kegiatan ini hanya sekedar sebuah permain yang mengandung unsur makhluk halus (gaib) yang memiliki kekuatan dan tidak sembarangan orang bisa memainkannya. Dalam pandangan masyarakat setempat kegiatan ini memiliki kekuatan yang kuat dari makhluk halus, kekuatan yang kuat ini bersumber dari energi manusia yang memegang boneka lukah.

\section{SIMPULAN}

Berdasarkan hasil penelitian,
dapat disimpulkan tentang makna kontekstual dalam lagu lukah gilo pada masyarakat Kabupaten Tebo Provinsi Jambi (struktural hermeneutik) yang mencakup sebagai berikut:

1. Makna kontekstual pada lirik lagu lukah gilo terkait dengan makna leksikal.

2. Makna kontekstual yang terkait dengan konteks situasi (tempat dan waktu). Pada situasi tempat lagu lukah gilo memiliki 3 tempat, yaitu: pendopo, hutan dan lapangan. Pada situasi waktu pada lukah gilo tidak ada batasan waktu.

3. Makna kontekstual yang terkait dengan bidang kebudayaan yang terdapat pada lirik yasi-yasi sifat sia lukah.

4. Makna kontekstual yang terkait dengan bidang animisme yang terdapat pada lirik lah galenggang tumbohlah direnah capo-capo tumbohlah dibukit, ilie lukah mudik lukah, main lukah jangan dipemudah, tepuk jari sebelah kiri tepuk sampai atas kepalo, lenggok kanan lenggok kiri orang nengoklah segalo, hutan tasik hutan tunggal jatuh melayang selere ngenyong, lah babisik jin tunggal utak benak dikepalo ngenyong.

5. Makna kontekstual yang terkait dengan bidang keyakinan yang terdapat pada lirik cek lukah pandailah menari, lah kaduduk tumbohlah direnah buat budak lanjarlah ketolo dan minta selamat lukahlah dipakai orang banyak nengoklah segalo.

\section{SARAN}

Berdasarkan simpulan yang didapat, saran dalam penelitian ini adalah sebagai berikut.

1. Lagu Lukah Gilo ialah salah satu jenis sastra lisan yang menggunakan bahasa daerah, disarankan pemerintah daerah untuk melestarikan kosakata bahasa daerah melalui kesenian seperti lagu Lukah Gilo dan sastra lainnya.

2. Disarankan agar pemerintah dinas pariwisata dan pendidikan untuk menyebar luaskan informasi tentang budaya daerah ke masyarakat luar.

3. Diharapkan agar dinas pariwisata dan pendidikan memberi pelatihan kepada guru atau penggiat budaya untuk meningkatkan pemahaman tentang keyakinan yang terkandung pada larik-larik lagu.

\section{DAFTAR PUSTAKA}

Chaer, Abdul. (2002). Pengantar Semantik Bahasa Indonesia. Jakarta: PT Rineka Cipta. 
Chaer, Abdul. (2007). Leksikologi dan Leksikografi Indonesia. Jakarta: PT Rineka Cipta.

Allen, Pamela. (2004). Membaca, dan Membaca Lagi. Tanggerang: AgroMedia Pustaka

Anshari. (2009). Hermeneutik sebagai Teori dan Metode Interpretasi Makna Teks Sastra. Jurnal Sawerigading, Vol.15, No. 2.

Dora, Nur Iza. (2018). Kajian Kearifan Lokal Masyarakat "Melayu" Ujung Gading. Jurnal Ijtimaiyah, Vol. 2. No.1.

Fitrah Muh dan Luthfiyah. (2017). Metodologi Penelitian; Penelitian Kualitatif, Tindakan Kelas \& Studi Kasus. Jawa Barat: CV Jejak.

Gunawan, E., Rahima, A., \& Supriyati, S. (2018). Analisis Tema ungkapan Tradisional Bapeno di Desa Hiang Kecamatan Sitinjau Laut Kabupaten Kerinci Provinsi. Aksara: Jurnal Ilmiah Pendidikan Bahasa dan Sastra Indonesia, 2(1), 130-141.

Margono, S. (2014). Metodologi Penelitian Pendidikan. Jakarta: PT Rineka Cipta.

Muhammad. (2011). Metode Penelitian Bahasa. Yogyakarta: Ar-ruzz Media.

Putra, Berlian Juwanda. (2014). Perbandingan Persepsi Siswa Terhadap Lagu Daerah dan Lagu Pop di SMA negeri 1 Muntilan. Universitas Negeri Yogyakarta.

Pramudita, Meylana. (2016). Pembelajaran Lagu Daerah dalam Menanamkan Apresiasi Siswa Kelas V SD 3 Blimbing Kidul Kabupaten Kudus. Universitas Negeri Semarang.

Rahima, A., \& Ridwan, S. (2016). Religious Values in the Theme Structure of Traditional Seloko of
Jambi Malay. Ijlecr-International Journal Of Language Education And Culture Review, 2 (1), 82-91.

Rahima, Ade. (2017). Interpretasi Makna Simbolik Ungkapan Tradisional Seloko Hukum Adat Melayu Jambi. Jurnal Ilmiah Universitas Batanghari, Vol. 17, No. 1.

Rahima, A. (2017). Nilai Nilai Religius Seloko Adat Pada Masyarakat Melayu Jambi (Telaah truktural Hermeneutik). Jurnal Ilmiah Universitas Batanghari Jambi, 14(4), 1-8.

Rofii, Afif. (2017) "Model Of Contextual-Based Semantics Learning Materials (Research And Development At Indonesian Language And Literature Education Department, Faculty Of Teachers Training And Education Batanghari University Jambi)", in Proceedings Sixth International Conference on Languages and Arts (ICLA) Advances in Social Science, Education, and Humanities Research (ASSER), vol. 148,2017

Rofii, Afif. dan Hasibuan, Rizka Rani (2019) Interferensi Bahasa Batak Mandailing dalam Tuturan Berbahasa Indonesia Pada Acara Parpunguan Masyarakat Mandailing Kota Jambi. Aksara. Aksara: Jurnal Ilmiah Pendidikan Bahasa dan Sastra Indonesia Vol. 3 No. 1 April 2019 aksara.unbari.ac.id/index.php/aksa $\mathrm{ra} /$ article/download/94/50.

Saidi, Acep Iwan. (2008). Hermeneutika Sebuah Cara untuk Memahami Teks. Jurnal Sosioteknologi, Vol.13, No.7.

Sarinah. (2016). Ilmu Sosial Budaya Dasar. Yogyakarta: CV Budi Utama. 
Sugiyono. (2016). Metode Penelitian Kuantitatif, Kualitatif dan $R \& D$. Bandung: CV Alfabeta.

Sugiyono. (2007). Metode Penelitian Pendidikan. Bandung: $\quad \mathrm{CV}$ Alfabeta.

Sugono, Dendy. (2009). Mahir Berbahasa Indonesia dengan Benar. Jakarta: PT Gramedia Pustaka Utama.

Sutardi, Tedi. (2007). Antropologi Mengungkap Keragaman Budaya. Bandung: PT Setia Purna Inves.

Suwandi, Sarwiji. (2011). Semantik Pengantar Kajian Makna. Yogyakarta: Media Perkasa.

Widjono, Hs. (2007). Bahasa Indonesia. Jakarta: PT Grasindo.

Yanti, Prima Gusti, dkk. (2017). Bahasa Indonesia Konsep Dasar dan Penerapan. Jakarta: PT Grasindo. 